九州大学学術情報リポジトリ

Kyushu University Institutional Repository

\title{
Effect of C0_2 Flow Rate on Enzyme Inactivation by Continuous Method with Microbubbles of Supercritical Carbon Dioxide
}

\section{Yoshimura, Takashi}

Laboratory of Food Process Engineering, Division of Food Biotechnology, Department of Bioscience and Biotechnology, Graduate School of Bioresource and Bioenvironmental Sciences, Kyushu University

Shimoda, Mitsuya

Laboratory of Food Process Engineering, Division of Food Biotechnology, Department of Bioscience and Biotechnology, Graduate School of Bioresource and Bioenvironmental Sciences, Kyushu University

Ishikawa, Hiroya

Laboratory of Food Analysis, Division of Food Biotechnology, Department of Bioscience and Biotechnology, Graduate School of Bioresource and Bioenvironmental Sciences, Kyushu University

Miyake, Masaki

Shimadzu Co.

他

https://doi.org/10.5109/24448

出版情報: 九州大学大学院農学研究院紀要. 46 (2)，pp.345-352，2002-02-28. Kyushu University バージョン：

権利関係: 


\title{
Effect of $\mathrm{CO}_{2}$ Flow Rate on Enzyme Inactivation by Continuous Method with Microbubbles of Supercritical Carbon Dioxide
}

\author{
Takashi YOSHIMURA, Mitsuya SHIMODA, Hiroya ISHIKAWA*, \\ Masaki MIYAKE**, Kiyoshi MATSUMOTO*, Yutaka OSAJIMA***, \\ and Isao HAYAKAWA
}

\begin{abstract}
Laboratory of Food Process Engineering, Division of Food Biotechnology, Department of Bioscience and Biotechnology, Graduate School of Bioresource and Bioenvironmental Sciences, Kyushu University, 10-1, 6-chome Hakozaki, Higashi-ku, Fukuoka city, Fukuoka, 812-8581, Japan.

(Received October 30, 2001 and accepted November 20, 2001)
\end{abstract}

\begin{abstract}
In our previous papers, batch treatment with microbubbles of supercritical carbon dioxide $\left(\mathrm{SC}-\mathrm{CO}_{2}\right)$ was established as an alternative method to heat treatment. For adapting to food industry, continuous system with microbubbles of $\mathrm{SC}_{-} \mathrm{CO}_{2}$ was designed and constructed. In continuous system, there are new factors affecting inactivation efficiency of microbubbles $\mathrm{SC}-\mathrm{CO}_{2}$ treatment. In this paper, effect of $\mathrm{CO}_{2}$ flow rate on enzyme inactivation by continuous method with microbubbles of $\mathrm{SC}-\mathrm{CO}_{2}$ was investigated. Dissolved $\mathrm{CO}_{2}$ concentration, which played an important role for enzyme inactivation by microbubbles $\mathrm{SC}-\mathrm{CO}_{2}$ treatment, was enhanced depending on $\mathrm{CO}_{2}$ flow rate. Also, it was observed that $\mathrm{pH}$ of deionized water was lowered to below 3 during the treatment. $\alpha$-amylase, which was thermoresistant enzyme, was easily inactivated at low $\mathrm{CO}_{2}$ flow rate because of temporary lowering of $\mathrm{pH}$. On the other hand, inactivation efficiency of acid protease, which was acid-resistant enzyme, was increased depending on $\mathrm{CO}_{2}$ flow rate.
\end{abstract}

\section{INTRODUCTION}

In food industry, heat treatments generally have been used for inactivation of enzymes and microorganisms. These treatments, however, result in critical damages of the food quality, such as flavor and taste. Therefore, developments of a novel method have been desired, and many researchers have tried to establish alternative methods, such as hydrostatic pressure, microwave heating, pulsed electric field, and so on. Seyderhelm et al. (1996) have reported inactivation of pectinesterase, polyphenol oxidase, peroxidase, lipase, lipoxygenase, and so on, using ultra high pressure treatment, but impractical high pressure (higher than $500 \mathrm{MPa}$ ) was needed for their significant inactivation. Yen and Lin (1996) have described that inactivation of pectinesterase and polyphenol oxidase was difficult by hydrostatic pressure treatment at $25^{\circ} \mathrm{C}$ and $600 \mathrm{MPa}$ for $15 \mathrm{~min}$. Ancos et al. (1999) have used microwave heating for inactivation of polyphenol oxidase and peroxidase in strawberry, papaya and kiwi. Although these treatments

* Laboratory of Food Analysis, Division of Food Biotechnology, Department of Bioscience and Biotechnology, Graduate School of Bioresource and Bioenvironmental Sciences, Kyushu University, 10-1, 6-chome Hakozaki, Higashi-ku, Fukuoka, 812-8581, Japan.

** Shimadzu Co., 1, Nishinokyo-kuwabara-cho, Nakagyo-ku, Kyoto, 604-8511, Japan.

*** Kyushu Women's University, 1-1, Jiyugaoka, Yahata-nishi-ku, Kitakyushu city, Fukuoka, 807-8586, Japan. 
have demonstrated higher inactivation efficiency rather than heat treatment, they are not widely applied to the industrial world because of cost for apparatus or difficulty to design continuous system, and so on.

In recent years, supercritical fluids have been used as environmentally benign media in various fields, such as enzymatic reactions (Kamat et al., 1993; Randolph et al., 1998; Mesiano et al., 1999), extractions (Ibáñez et al., 1999; Simándi et al., 1999), dyeing (Sicardi et al., 1999; Santos et al., 2001), degradation of polymer compounds (Savage, 1999; Kim et al., 2001). In such fluids, supercritical carbon dioxide $\left(\mathrm{SC}-\mathrm{CO}_{2}\right)$ has several advantages, such as nontoxicity, nonflammable, and no residual chemical problem. Also, $\mathrm{SC}-\mathrm{CO}_{2}$ is fluid that is easy to operate because of moderate critical temperature and pressure (critical temperature; $31.1^{\circ} \mathrm{C}$ : critical pressure; $7.4 \mathrm{MPa}$ ).

We have developed an alternative method with microbubbles of $\mathrm{SC}_{-} \mathrm{CO}_{2}$ for inactivation of enzymes and microorganisms in liquid product (sake, juices, and so on) under moderate conditions (Ishikawa et al., 1995, 1996a, 1997). In the previous papers, batch system was used for inactivation of enzymes and microorganisms. For improving the treatment efficiency and adapting microbubbles of $\mathrm{SC}-\mathrm{CO}_{2}$ method to food industry, a new apparatus for continuous system with microbubbles $\mathrm{SC}-\mathrm{CO}_{2}$ was designed and constructed. In a batch method, temperature, pressure and time related to microbubbles $\mathrm{SC}-\mathrm{CO}_{2}$ treatment are main operating factor, whereas in a continuous system, there are new factors for affecting inactivation efficiency of microbubbles $\mathrm{SC}-\mathrm{CO}_{2}$ treatment, such as $\mathrm{CO}_{2}$ flow rate. Our previous papers have reported that inactivation of enzymes and microorganisms by batch method with microbubbles of $\mathrm{SC}-\mathrm{CO}_{2}$ was predominantly affected to dissolved $\mathrm{CO}_{2}$ concentration during the treatment. In this paper, we tried to evaluate dissolved $\mathrm{CO}_{2}$ concentration during continuous method with microbubbles of $\mathrm{SC}-\mathrm{CO}_{2}$, and elucidate the effect of $\mathrm{CO}_{2}$ flow rate on enzyme inactivation by continuous method with microbubbles of $\mathrm{SC}-\mathrm{CO}_{2}$.

\section{MATERIALS AND METHODS}

\section{Continuous treatment with microbubbles of $\mathrm{SC}-\mathrm{CO}_{2}$}

For continuous treatment with microbubbles of $\mathrm{SC}-\mathrm{CO}_{2}$, an instrument was manufactured by Shimadzu Co. (Kyoto, Japan) according to our design (Figure 1). Sample and liquid $\mathrm{CO}_{2}$ were simultaneously pumped through a treatment vessel $(2.8 \mathrm{~cm}$ i.d. $\times 35 \mathrm{~cm}$ long, $215 \mathrm{~mL}$ of inner volume) in respective flow rates with plunger-type variable speed compressors. Liquid $\mathrm{CO}_{2}$ changed to gaseous or supercritical state when came into evaporator before treatment vessel, and then was supplied to treatment vessel through a micropore filter $(10 \mu \mathrm{m}$ of pore size). Treatment time is defined as average residence time (RT) calculated from sample flow rate and inner volume of treatment vessel.

\section{Measurement of $\mathrm{CO}_{2}$ concentration in deionized water during continuous treat- ment with microbubbles of $\mathrm{SC}-\mathrm{CO}_{2}$}

Dissolved $\mathrm{CO}_{2}$ concentration in deionized water during continuous treatment with microbubbles of $\mathrm{SC}-\mathrm{CO}_{2}$ was measured using dry gas meter. After depressurization to atmospheric pressure, $\mathrm{CO}_{2}$ that could not dissolve in deionized water was separated from the solution because excess $\mathrm{CO}_{2}$ dissolved in deionized water during microbubbles 


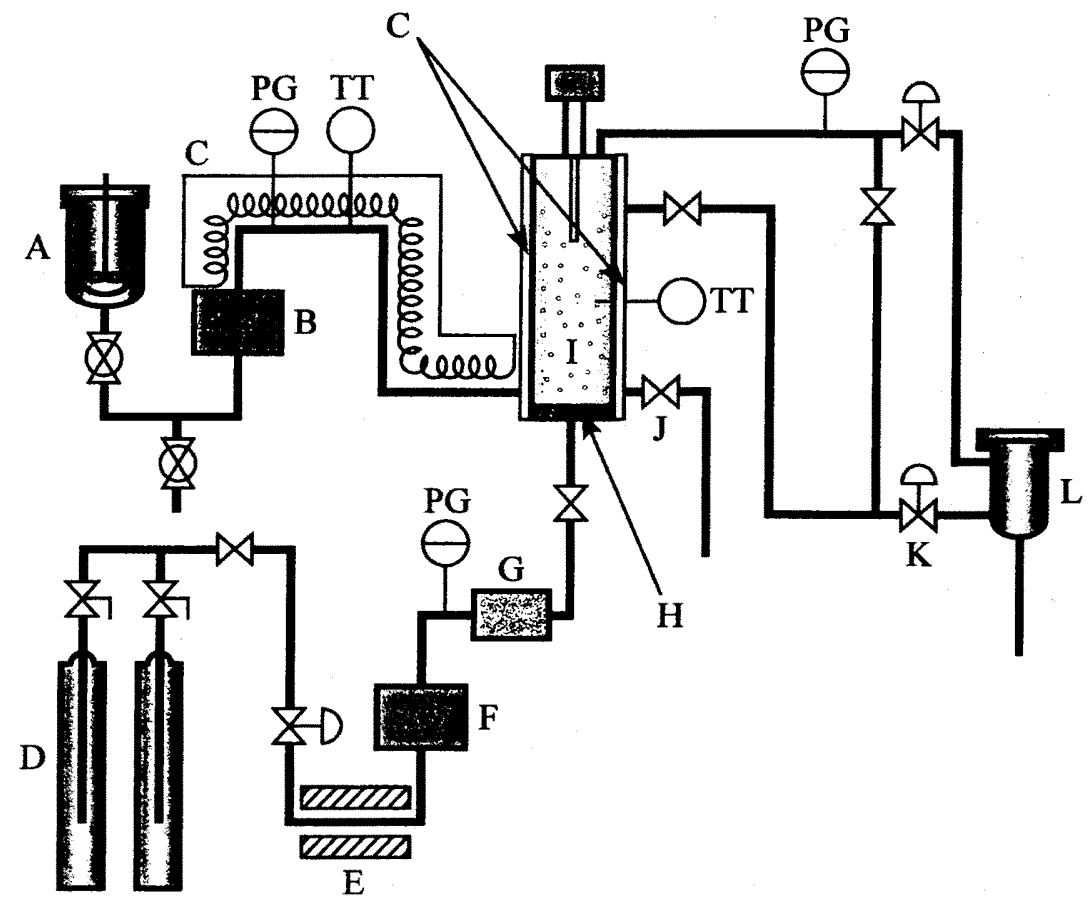

Fig. 1. Schematic of apparatus for continuous treatment with microbubbles of $\mathrm{SC}-\mathrm{CO}_{2}$. Symbols indicate: A, sample vessel; B, sample pump; C, heater; $\mathrm{D}, \mathrm{CO}_{2}$ cylinder; $\mathrm{E}$, cooling unit; $\mathrm{F}, \mathrm{CO}_{2}$ pump; $\mathrm{G}$, evaporator; $\mathrm{H}$, micropore filter $(10 \mu \mathrm{m}$ of pore size); I, treatment vessel ( $215 \mathrm{~mL}$ of inner volume); J, drain valve; $\mathrm{K}$, pressure-regulating valve; $\mathrm{L}$, product vessel; $\mathrm{PG}$, pressure gauge; $\mathrm{TT}$, thermoelectric thermometer.

SC- $-\mathrm{CO}_{2}$ treatment. Treated solution and separated $\mathrm{CO}_{2}$ passed through a trap for dividing $\mathrm{CO}_{2}$ from treated solution. Then, the volume of separated $\mathrm{CO}_{2}$ was measured with dry gas meter. The $\mathrm{CO}_{2}$ concentration was calculated as Kuenen coefficient. Kuenen coefficient is defined as a volume $(\mathrm{mL})$ of gas at $0^{\circ} \mathrm{C}$ and $760 \mathrm{mmHg}$ calculated from a volume of gas dissolved into $1 \mathrm{~g}$ of a solvent at arbitrary temperature and pressure.

\section{Observation of pH change in treatment vessel during continuous treatment with microbubbles of $\mathrm{SC}-\mathrm{CO}_{2}$}

A treatment vessel equipped with a pressure-resistant window was used for visual observation of $\mathrm{pH}$ change during continuous treatment with microbubbles of $\mathrm{SC}-\mathrm{CO}_{2}$. Bromophenol blue (BPB) and thymol blue as $\mathrm{pH}$ indicators were dissolved in water, and then subjected to continous treatment with microbubbles of $\mathrm{SC}-\mathrm{CO}_{2}$. During treatment, the change of $\mathrm{pH}$ in the treatment vessel was photographically observed.

\section{Preparation of enzyme solutions}

$\alpha$-Amylase from Bacillus subtilis (EC.3.2.1.1, Amano Enzyme Inc., Nagoya, Japan) 
and acid protease from Aspergillus niger (EC.3.4.23.6, Hankyu Bioindustry Co., Ltd., Osaka, Japan) were dissolved in deionized water in a concentration of $0.1 \mathrm{mg} \mathrm{mL}^{-1}$. And then each enzyme solution was subjected to continuous treatments with microbubbles of $\mathrm{SC}-\mathrm{CO}_{2}$ at arbitrary conditions.

\section{Measurements of enzyme activity}

$\alpha$-Amylase; The activity of $\alpha$-amylase was measured by using amylase assay kit (amylase B-test Wako from Wako Pure Chemical Industry, Osaka, Japan). One unit of the enzyme activity is defined as the amount of enzyme required to degrade fully $10 \mathrm{mg}$ of starch at $37^{\circ} \mathrm{C}$ for $30 \mathrm{~min}$.

Acid protease; the activity of acid protease was determined by the method of Ishikawa et al. (1995). One unit of enzyme activity is defined as the amount of enzyme required to liberate $1 \mu \mathrm{g}$ of tyrosine per $60 \mathrm{~min}$ under the assay conditions.

\section{Residual activity}

The residual activity was defined as a percentage of the activity (units $\mathrm{mL}^{-1}$ ) of enzyme solution after continuous treatment with microbubbles of $\mathrm{SC}-\mathrm{CO}_{2}$ against the activity (units $\mathrm{mL}^{-1}$ ) of enzyme solution prepared.

\section{RESULTS AND DISCUSSION}

Figure 2 indicates behavior of dissolved $\mathrm{CO}_{2}$ concentration in deionized water during continuous treatment with microbubbles of $\mathrm{SC}-\mathrm{CO}_{2}$. Continuous treatments with

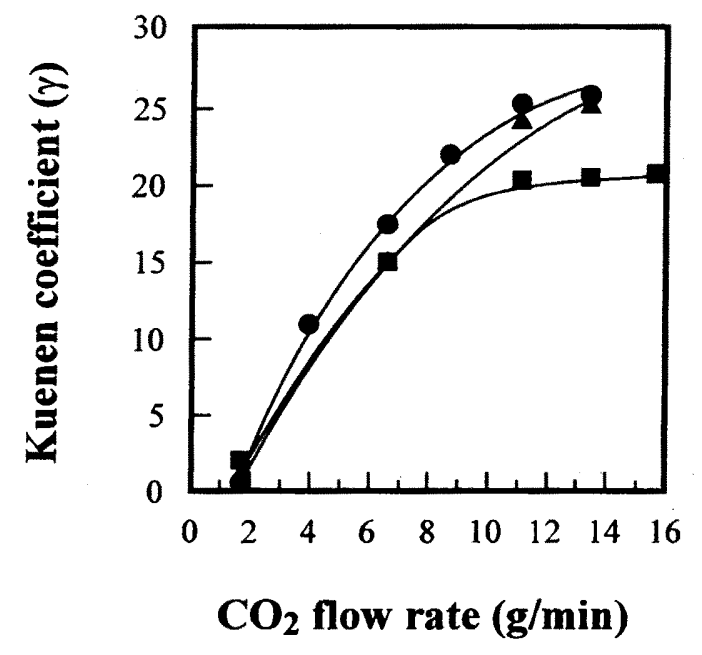

Fig. 2. Effect of $\mathrm{CO}_{2}$ flow rate on dissolved $\mathrm{CO}_{2}$ concentration during continuous treatment with microbubbles of $\mathrm{SC}-\mathrm{CO}_{2}$. Microbubbles $\mathrm{SC}-\mathrm{CO}_{2}$ treatment was carried out at $35^{\circ} \mathrm{C}(\mathbf{O}), 40^{\circ} \mathrm{C}$ (A), $45^{\circ} \mathrm{C}(\square), 10 \mathrm{MPa}$ and $15.6 \mathrm{~g}-\mathrm{CO}_{2} / \mathrm{min}$ for $5 \mathrm{~min}$ of RT. 
microbubbles of $\mathrm{SC}-\mathrm{CO}_{2}$ were carried out at $35,40,45^{\circ} \mathrm{C}$, and $10 \mathrm{MPa}$ for $5 \mathrm{~min}$ of $\mathrm{RT}$. The dissolved $\mathrm{CO}_{2}$ concentration was enhanced depending on $\mathrm{CO}_{2}$ flow rate. At $10 \mathrm{MPa}$ and $13.4 \mathrm{~g}-\mathrm{CO}_{2} / \mathrm{min}$, Kuenen coefficient was 26.1 at $35^{\circ} \mathrm{C}, 25.3$ at $40^{\circ} \mathrm{C}$ and 20.7 at $45^{\circ} \mathrm{C}$. The saturated concentrations at $10 \mathrm{MPa}$ and each temperature were 29.1 at $35^{\circ} \mathrm{C}, 27.8$ at $40^{\circ} \mathrm{C}$ and 26.5 at $45^{\circ} \mathrm{C}$, respectively. Irrespective of the changes in sample flow rates and treatment pressure, dissolved $\mathrm{CO}_{2}$ concentration enhanced similarly (data not shown). In batch system, Ishikawa et al. (1995) have reported that increase of dissolved $\mathrm{CO}_{2}$ concentration in sample solution played an important for enzyme inactivation because higher inactivation effect was obtained with higher dissolved $\mathrm{CO}_{2}$ concentration. Therefore, this continuous system with microbubbles of $\mathrm{SC}_{-}-\mathrm{CO}_{2}$ might be able to inactivate enzymes regardless of treatment conditions.

Arreora et al. (1991) and Balaban el al. (1991) have described that enzyme inactivation by $\mathrm{SC}-\mathrm{CO}_{2}$ treatment was based on the temporary lowering of $\mathrm{pH}$ during treatment because dissolution of high-pressure $\mathrm{CO}_{2}$ molecules to water resulted in production of carbonic acid. Then, using $\mathrm{BPB}$ and thymol blue as $\mathrm{pH}$ indicators, the change of $\mathrm{pH}$ during microbubbles $\mathrm{SC}-\mathrm{CO}_{2}$ treatment was visually observed (Figure 3). Continuous treatment with microbubbles of $\mathrm{SC}-\mathrm{CO}_{2}$ was carried out at $35^{\circ} \mathrm{C}, 20 \mathrm{MPa}$, and
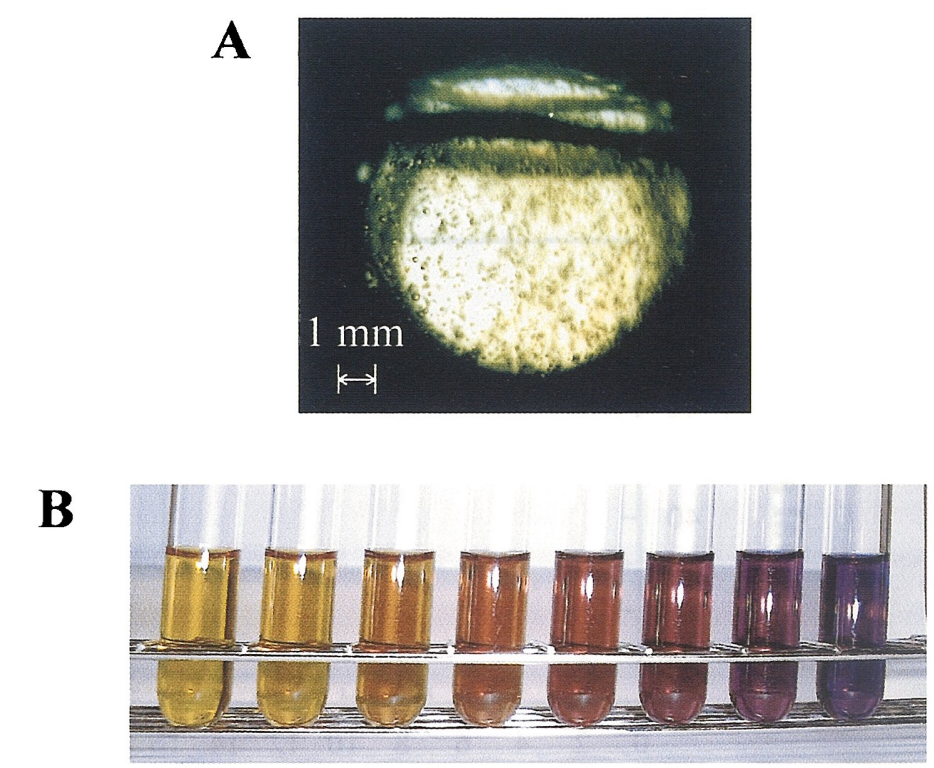

\section{$\begin{array}{lllllllll}\text { pH } & 2.7 & 3.0 & 3.3 & 3.6 & 3.9 & 4.2 & 4.5 & 4.8\end{array}$}

Fig. 3. $\mathrm{pH}$ change of deionized water induced by continuous treatment with microbubbles of $\mathrm{SC}-\mathrm{CO}_{2}(\mathrm{~A})$. Microbubbles $\mathrm{SC}-\mathrm{CO}_{2}$ treatment was carried out at $35^{\circ} \mathrm{C}, 20 \mathrm{MPa}$ and $15.6 \mathrm{~g}-\mathrm{CO}_{2} / \mathrm{min}$ for $5 \mathrm{~min}$ of RT. Photograph of $\mathrm{B}$ shows color difference of $\mathrm{BPB}$ at each $\mathrm{pH}$ value in Mcllvaine buffer. 
$15.6 \mathrm{~g}-\mathrm{CO}_{2} / \mathrm{min}$. Before the treatment, BPB solution indicated blue (higher than $\mathrm{pH} 4.6$ ), and then, the color of the treating solution turned to yellow (less than $\mathrm{pH} 3.0$ ). After the treatment, BPB solution returned to blue. On the other hand, the color of thymol blue, which indicates from $\mathrm{pH} 1.2$ to $\mathrm{pH} 2.8$, did not change before and during the treatment, that is, the $\mathrm{pH}$ during the treatment was above 2.8 (data not shown). Toews et al. (1995) have reported that the $\mathrm{pH}$ of water in contact with $\mathrm{CO}_{2}$ at subcritical and supercritical state ranged between 2.8 and 2.95 at $25-70^{\circ} \mathrm{C}$ and $70-200 \mathrm{~atm}$. This report agrees with our results, hence temporary lowering of $\mathrm{pH}$ was occurred during continuous treatment with microbubbles of $\mathrm{SC}-\mathrm{CO}_{2}$.

The effect of $\mathrm{CO}_{2}$ flow rate on inactivation of $\alpha$-amylase by continuous treatment with microbubbles of $\mathrm{SC}-\mathrm{CO}_{2}$ is shown in Figure 4. Continuous treatment with microbubbles of $\mathrm{SC}-\mathrm{CO}_{3}$ was carried out at $35^{\circ} \mathrm{C}, 30 \mathrm{MPa}$ for $15 \mathrm{~min}$ of RT. $\alpha$-amylase is heat-stable enzyme. After heat treatment at $70^{\circ} \mathrm{C}$ for $15 \mathrm{~min}$, residual activity of this enzyme decreased to $97.9 \%$. On the other hand, after microbubbles $\mathrm{SC}-\mathrm{CO}_{2}$ treatment, $\alpha$-amylase was completely inactivated in low $\mathrm{CO}_{2}$ flow rate $\left(4.0 \mathrm{~g}-\mathrm{CO}_{2} / \mathrm{min}\right)$. When $\alpha$ -amylase dissolved in Mcllvaine buffer ( $\mathrm{pH} 3.0$ ) was treated with heat at $35^{\circ} \mathrm{C}$ for $15 \mathrm{~min}$, the residual activity was $1.0 \%$ (data not shown). Optimum $\mathrm{pH}$ of $\alpha$-amylase is $5.8-6.8$, therefore it was considered that inactivation of $\alpha$-amylase by continuous treatment with microbubbles of $\mathrm{SC}-\mathrm{CO}_{2}$ was mainly attributed to lowering of $\mathrm{pH}$ during the treatment in spite of lower $\mathrm{CO}_{2}$ flow rate.

Figure 5 illustrates effect of $\mathrm{CO}_{2}$ flow rate on inactivation of acid protease by continuous treatment with microbubbles of $\mathrm{SC}-\mathrm{CO}_{2}$. Continuous treatments with microbub-

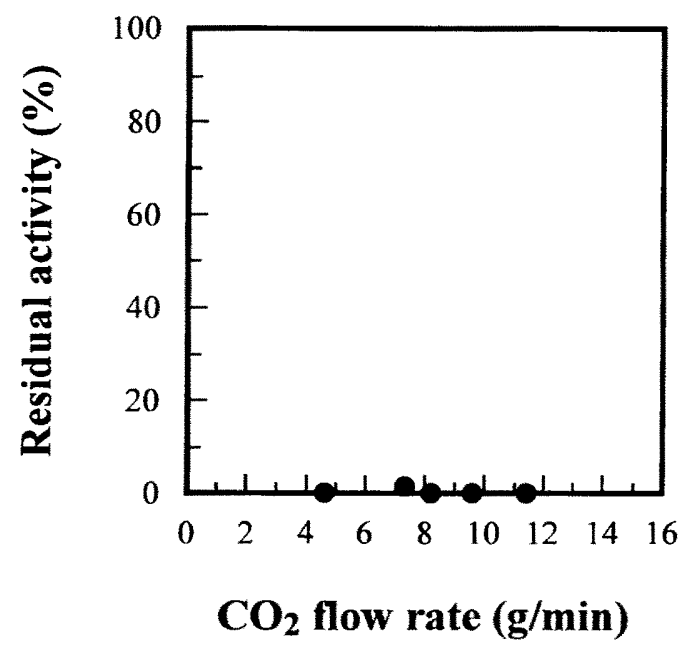

Fig. 4. Effect of $\mathrm{CO}_{2}$ flow rate on inactivation of $\alpha$ -amylase by continuous treatment with microbubbles of $\mathrm{SC}-\mathrm{CO}_{2}$. Microbubbles $\mathrm{SC}-\mathrm{CO}_{2}$ treatment was carried out at $30 \mathrm{MPa}$ and $15.6 \mathrm{~g}-\mathrm{CO}_{2} / \mathrm{min}$ for $15 \mathrm{~min}$ of RT. Symbol indicates: $35^{\circ} \mathrm{C}$. 


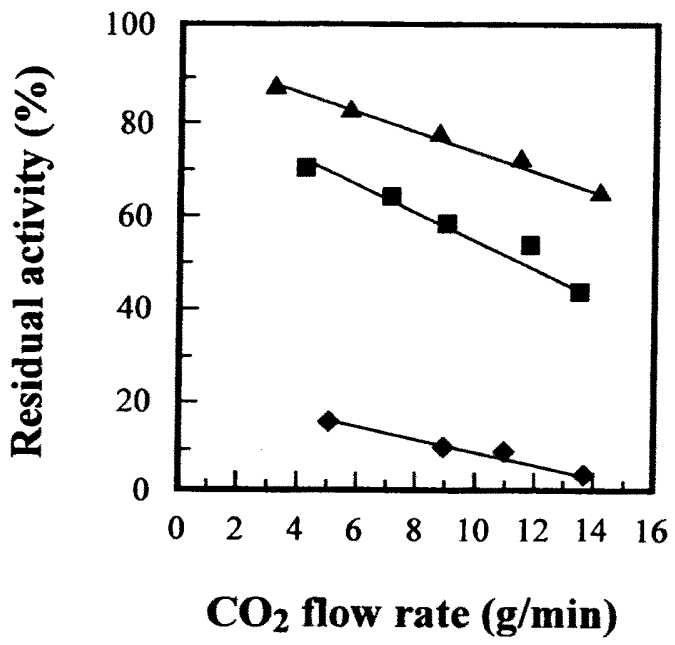

Fig. 5. Effect of $\mathrm{CO}_{2}$ flow rate on inactivation of acid protease by continuous treatment with microbubbles of $\mathrm{SC}-\mathrm{CO}_{2}$. Microbubbles $\mathrm{SC}-\mathrm{CO}_{2}$ treatments were carried out at $30 \mathrm{MPa}$ and $15.6 \mathrm{~g}-\mathrm{CO}_{2} / \mathrm{min}$ for $15 \mathrm{~min}$ of RT. Symbols indicate: $\triangle, 40^{\circ} \mathrm{C} ; \mathbf{D}, 45^{\circ} \mathrm{C} ; 50^{\circ} \mathrm{C}$.

bles of $\mathrm{SC}-\mathrm{CO}_{2}$ were carried out at $40^{\circ} \mathrm{C}, 45^{\circ} \mathrm{C}, 50^{\circ} \mathrm{C}$, and $30 \mathrm{MPa}$ for $15 \mathrm{~min}$ of RT. After heat treatment at $50^{\circ} \mathrm{C}$ for $15 \mathrm{~min}$, residual activity of acid protease was $88.6 \%$ in deionized water and $90.6 \%$ in Mcllvaine buffer ( $\mathrm{pH} 3.0$ ). After microbubbles $\mathrm{SC}-\mathrm{CO}_{2}$ treatment, residual activity decreased in proportion to $\mathrm{CO}_{2}$ flow rate at each temperature. Residual activities after microbubbles $\mathrm{SC}-\mathrm{CO}_{2}$ treatment decreased from $85.5 \%$ $\left(3.2 \mathrm{~g}-\mathrm{CO}_{2} / \mathrm{min}\right)$ to $63.0 \%\left(14.2 \mathrm{~g}-\mathrm{CO}_{2} / \mathrm{min}\right)$ at $40{ }^{\circ} \mathrm{C}$, from $68.5 \%\left(4.2 \mathrm{~g}-\mathrm{CO}_{2} / \mathrm{min}\right)$ to $42.2 \%$ $\left(13.5 \mathrm{~g}-\mathrm{CO}_{2} / \mathrm{min}\right)$ at $45^{\circ} \mathrm{C}$, and $14.9 \%\left(5.1 \mathrm{~g}-\mathrm{CO}_{2} / \mathrm{min}\right)$ to $3.2 \%\left(13.7 \mathrm{~g}-\mathrm{CO}_{2} / \mathrm{min}\right)$ at $50^{\circ} \mathrm{C}$. Ishikawa et al. (1996b) have described that inactivation effects were mainly attributed to $\mathrm{pH}$-lowering effect and subsequently conformational change was caused by $\mathrm{CO}_{2}$ molecules, that is irreversible destruction of $\alpha$-helix. Kamat et al. (1995a, 1995b) have reported that the carbamate complexes were formed between amino groups on enzyme surface and $\mathrm{CO}_{2}$ molecules. From these results it was considered that temporary lowering of $\mathrm{pH}$ induced by dissolution of $\mathrm{CO}_{2}$ could influence conformation of enzyme, and then the contact of $\mathrm{CO}_{2}$ molecules with amino groups on the enzyme surface was enhanced by the increase of $\mathrm{CO}_{2}$ flow rate, as a result, enzymes were inactivated.

These results lead to the conclusion that $\mathrm{CO}_{2}$ flow rate plays a significant role to enhance not only dissolved $\mathrm{CO}_{2}$ concentration but also inactivation efficiency. Therefore, it was suggested that continuous treatment with microbubbles of $\mathrm{SC}-\mathrm{CO}_{2}$ might be inactivating various enzymes more easily.

\section{REFERENCES}

Ancos B, Cano MP, Hernandez A, Monreal M. 1999 Effects of microwave heating on pigment 
composition and color of fruit purees. J. Sci. Food Agric., 79: 663-670

Arreora, A. G., Balaban, M. O., Marshall, M., Peplow, A., Wei, C. 1., Cornell, J. A. 1991 Supercritical Carbon Dioxide Effects on Some Quality Attributes of Single Strength Orange Juice. J. Food Sci., 56, 1030-1033

Balaban, M. O., Arreora, A. G., Marshall, M., Peplow, A., Wei, C. I., Cornell, J. A. 1991 Inactivation of Pectinesterase in Orange Juice by Supercritical Carbon Dioxide. J. Food Sci, , 56, 743-746

Ibáñez, E., Oca, A., Murga, G., López-Sebastián, S., Tabera, J., Reglero, G. 1999 Supercritical fluid extraction and fractionation of different preprocessed rosemary plants. J. Agric. Food Chem., 47: 1400-1404

Ishikawa, H., Shimoda, M., Kawano, T., Osajima, Y. 1995 Inactivation of Enzymes in an Aqueous Solution by Micro-bubbles of Supercritical Carbon Dioxide. Biosci. Biotech. Biochem., 59, 628-631

Ishikawa, H., Shimoda, M., Yonekura, A., Osajima, Y. 1996a Inactivation of Pectinesterase in Valencia Orange Juice by Micro-bubble Supercritical Carbon Dioxide Method. Nippon Shokuhin Kagaku Kogaku Kaishi, 43, 999-1003 (in Japanese)

Ishikawa, H., Shimoda, M., Yonekura, A., Osajima, Y. 1996b Inactivation of Enzymes and Decomposition of $\alpha$-helix Structure by Supercritical Carbon Dioxide Microbubble Method. J Agric. Food Chem., 44, 2646-2649

Ishikawa, H., Shimoda, M., Tamaya, K., Yonekura, A., Kawano T. Osajima, Y. 1997 Inactivation of Bacillus spores by the Supercritical Carbon Dioxide Micro-bubble Method. Biosci. Biotech. Biochem., 61, 1022-1023

Kamat, S. V., Iwaskewycz, B., Beckman E. J., Russell, A. J. 1993 Biocatalytic synthesis of acrylates in supercritical fluids: Tuning enzyme ativity by changing pressure. Proc. Natl. Acad. Sci. USA, 90: 2940-2944

Kamat, S. V., Beckman, E. J., Russell A. J. 1995a. Enzyme Activity in Supercritical Fluids, Crit. Rev. Biotechnol., 15, $41-71$

Kamat, S., Critchley, G., Beckman, E. J., Russell A. J. $1995 \mathrm{~b}$ Biocatalytic Synthesis of Acrylates in Organic Solvents and Supercritical Fluids: III. Does Carbon Dioxide Covalently Modify Enzymes?, Biotechnol. Bioeng., 46, 610-620

Kim, B.-K., Hwang, G.-C., Bae, S.-C., Kumazawa, H. 2001 Depolymerization of polyethyleneterephthalate in supercritical methanol. J. Appl. Polym.Sci, 81:2102-2108

Mesiano, A. J., Beckman E. J., Russell, A. J. 1999 Supereritical Biocatalysis. Chem. Rev., 99: 623-633

Randolph, T. W., Clark, D. S., Blanch, H. W., Prausnitz, J. M. 1998 Enzymatic oxidation of cholesterol aggregates in supercritical carbon dioxide. Science, 238: 387-390

Santos, W. L. F., Porto, M. F., Muniz, E. C., Povh, N. P., Rubira, A. F. 2001 Incorporation of disperse dye in $N, N$-dimethylacrylamide modified poly (ethylene terephthalate) fibers with supercritical $\mathrm{CO}_{2} . J$. Supercrit. Fluids, 19: 177-185

Savage, P. E. 1999 Organic chemical reactions in supercritical water. Chem. Rev., 99:603-621

Seyderhelm, I.; Bouguslawski, S.; Michaelis, G.; Knorr, D. 1996 Pressure induced inactivation of selected food enzymes. J. Food Sci., 61: 308-310

Sicardi, S., Manna, L., Banchero, M. 2000 Comparison of dye diffusion in poly (ethylene terephthalate) films in the presence of a supercritical or aqueous solvent. Ind. Eng. Chem. Res., 39: 4707-4713

Simándi, B., Deák, A., Rónyai, E. 1999 Supercritical carbon dioxide extraction and fractionation of fennel oil. J. Agric. Food Chem., 47: 1635-1640

Toews, K. L., Shroll, R. M., Wai, C. M., Smart, N. G. 1995 pH-Defining Equilibrium between Water and Supercritical $\mathrm{CO}_{2}$. Influence on SFE of Organics and Metal Chelates. Anal. Chem., 67, 4040-4043

Yen GC, Lin HT. 1996 Comparison of high pressure treatment and thermal pasteurization effects on the quality and shelf life of guava puree. Int. J. Food Sci. Tech., 31:205-213 